\title{
Ciało w odcieleśnionej rzeczywistości. "Tango" Kultury Zrzuty
}

DOI: 10.19195/2083-7763.8.4

Czy Ty wiesz, ile trzeba było odwagi, żeby tańczyć tango?

Sławomir Mrożek

W rzeczywistości PRL-u jakakolwiek tematyka erotyczna mogła mieścić się jedynie w niejawnej, prywatnej sferze obyczajowej, gdyż zabrakło dla niej miejsca w oficjalnym systemie światopoglądowym i aprobowanej ikonografii. Zaczęła być chętniej podejmowana w latach osiemdziesiątych przez tzw. Kulturę Zrzuty będącą nieokrzesanym piewcą erotyzmu ${ }^{1}$. Miejsce, w którym gromadziła się Kultura Zrzuty, było na ówczesnej mapie Polski inspirującym wymianę myśli ośrodkiem artystycznego fermentu, energetycznym centrum zabawy, wolną przestrzenią rozmaitych ekspresji, akcji performatywnych. Było to poddasze na głównej ulicy Łodzi - Piotrkowskiej 149, a zarazem, jak twierdzą bywalcy, jedyne miejsce, w którym można było wytrzymać w stanie wojennym. W latach 1980-1986 lódzka kontrkultura spotykała się na tzw. Strychu². Gromadzący się tam młodzi ludzie

1 Autorka korzystała z internetowego archiwum stworzonego przez Grażynę Łuczko-Fijałkowską (Zofię), znajdującego się pod adresem www.kulturazrzuty.pl. Zob. także A.F. Pawlak, Tworzenie alternatywnych rzeczywistości. Ruch artystyczny Kultura Zrzuty - perspektywa antropologiczna, Łódź 2016; J. Robakowski, Kultura Zrzuty, [w:] Nieme Kino II, oprac. M. Janiak et al., Antwerpia 1984; idem, Pitch-In Culture, [w:] Poolse 'avant-garde', Antwerp 1985; idem, Sztuka w poszukiwaniu miejsca, Koszalin 1988; idem, Sztuka Zrzuty, [w:] PST! czyli sygnia nowej sztuki (or Signs of New Art) 1981-1984, red. J. Robakowski, Warszawa 1989; idem, Kultura Zrzuty, [w:] Teksty interwencyjne 1970-1995, Słupsk 1995; idem, Kultura Zrzuty, „Neue Kunst in Europa (NIKE)” 1984, nr 3.

2 E. Nowina-Sroczyńska, Piotrkowska 149. Strych - przestrzeń pozbawiona kurtuazji, [w:] Przestrzenie i ludzie. Konteksty antropologiczne, red. G.E. Karpińska, A. Krupa-Ławrynowicz, Łódź 2015, s. 81-112. 
zapraszali do wejścia w przestrzeń radykalnego otwarcia. W łódzkiej bazie kontrkultury kultywowano postawy uznawane za niespójne z dominującym systemem myślenia. Było to miejsce, w którym doceniono erotyczny dowcip, humor i cielesność w aerotycznej rzeczywistości PRL-u.

Zauważmy, że społeczności alternatywne konstruują zwykle prywatną, specyficzną zonę, mającą gwarantować jak najgłębsze oderwanie danej grupy od struktur państwowych (oficjalnych). Aktywność opiera się na bezinteresownej pracy poszczególnych członków; można ją wyrazić hasłem „Zrób to sam” („Do It Yourself” - DIY). W historii ruchów awangardowych artyści zazwyczaj podejmowali akcje poza tradycyjną świątynią sztuki — galerią. Czynili tak dadaiści, surrealiści, akcjonista wiedeński Hermann Nitsch przeprowadzał wiele swoich działań w mieszkaniach zaprzyjaźnionych artystów, Richard Schechner zaś wystawił Dionysus 69 w zaadaptowanym w tym celu warsztacie określanym „Performance Garage”3. Gromadząc się na „podniebiu” łódzkiej kamienicy, młodzi ludzie ukierunkowani byli na ciągłe przeobrażanie własnego świata i przekraczanie rozmaitych granic - logistycznych, towarzyskich, artystycznych i społecznych. Dzięki temu mogli przemierzać socjalistyczny, szary świat w „znośnej lekkości bytu”. Zmienne konfiguracje towarzyskie, mnogość twórców proponujących rozmaite, niekiedy hybrydyczne, działania, kształtowały przez kolejne lata tożsamość bywalców Strychu. Umożliwiło to wchodzącym w dorosłe życie Zrzutowcom kontakt $\mathrm{z}$ autentycznymi postawami w czasie panujących w PRL-u pozorów i „podwójnej tożsamości”. Kultura Zrzuty była wspólnotą „przeżywania”, powoływała do istnienia nowy świat, a problem rozgraniczenia sztuki na profesjonalną i nieprofesjonalną postanowiono uznać za niemodny, nieistotny. Dzięki autonomicznej przestrzeni, jaką był Strych, powstała płaszczyzna komunikacji, kontekst dla spotkań, których uczestnicy mieli dość ersatzu socjalistycznego państwa i kreowanej przezeń fikcyjnej wspólnotowości. To właśnie tu po raz pierwszy, w połowie lat osiemdziesiątych, grupa Łódź Kaliska wykonała Casting wypornościowy, powtarzany w późniejszych okresach jeszcze kilkukrotnie, polegający na mierzeniu objętości damskich piersi poprzez zanurzenie ich w menzurkach wypełnionych wodą ${ }^{4}$. Casting wypornościowy cieszył się niezwykłym powodzeniem, a modelki - tzw. muzy - stanowiły dobrze sobie znany zespół kontynuujący znajomości na wyjazdach plenerowych czy spotkaniach prywatnych, na których współtworząca Kulturę Zrzuty grupa Łódź Kaliska odkryła swoje zamiłowanie do czasów niemego kina i urok erotycznych komedii Chaplina i braci Marx ${ }^{5}$. W wyniku oddolnej inicjatywy i samoorganizacji środowiska powstała „baza wolności i wyobraźni”,

${ }^{3}$ R. Schechner, Performatyka. Wstęp, przeł. T. Kubikowski, red. przekł. M. Rochowski, Wrocław 2006.

${ }^{4}$ J. Ciesielska, Trzy dekady Łodzi Kaliskiej. Zagadnienie erotyki w działaniach tej grupy, [w:] Biała Aura, Darłowo 2009.

${ }^{5}$ Z rozrzewnieniem wspominają te czasy po latach w filmie Anny Leśniak pt. Historia Łodzi Kaliskiej opowiedziana przez Muzy (2009) Anna Krawczyk, Małgorzata Kapczyńska-Dopierała, 
jaką był Strych, stanowiąc centrum dialogu i swobodnych działań dla łódzkiej kontrkultury i łącząc w „niemych czasach” środowisko młodych ludzi chcących mówić o erotyzmie. Podziały na artystów i nie-artystów nie odgrywały najistotniejszej roli, a nawet czyniono wiele zabiegów, aby granica między sceną a publicznością nigdy nie została wytyczona. Przypomnijmy, że spowodowana stanem wojennym izolacja PRL-u nie ułatwiała swobodnej międzynarodowej wymiany artystycznej. Kontakt ze światem zewnętrznym możliwy był głównie dzięki pracownikom i studentom Łódzkiej Szkoły Filmowej posiadającym zagraniczny paszport - to dzięki nim wieść o Strychu rozeszła się poza granicami kraju 6 .

W latach 1983-1986 na Strychu Kultura Zrzuty wytwarzała ręcznie artystyczny magazyn „Tango", będący dziś najważniejszym symbolem aktywności „heretyków sztuki”. Magazyn był wyrazem różnorodnych postaw przyjmowanych wobec świata przez dążących do totalnej emancypacji przedstawicieli kontrkultury, o czym świadczą zawarte w nim twórcze obserwacje rzeczywistości. Warto przypomnieć, że w latach osiemdziesiątych istniały trzy obiegi informacji. Do pierwszego z nich należały kontrolowane i podległe komunistom media oficjalne, $\mathrm{w}$ drugim zaś drukowano wydawnictwa zdelegalizowanej „Solidarności” i innych opozycyjnych wobec systemu odłamów opozycji. Trzeci obieg był niezależny od tych dwóch porządków i stanowił konstelację ulotnych druków, gazetek, fanzinów związanych $\mathrm{z}$ podziemiem. O ile tematyka poruszana $\mathrm{w}$ drugim obiegu i podziemnej prasie opozycyjnej z lat 1981-1988 nie podważała tradycyjnej obyczajowości i sytemu wartości, na którego straży stał Kościół katolicki, o tyle treści takie pojawiały się $\mathrm{w}$ radykalnym, anarchistycznym obiegu alternatywnym, atakującym z taką samą mocą działalność komunistycznego państwa oraz proponowane przez antykomunistyczną opozycję wyobrażenia społeczne. W odniesieniu do inicjatyw kontrkulturowych popularnym medium stał się własnoręcznie tworzony zin. Zauważmy jednak, że zarówno w drugim, jak i trzecim obiegu pojawiały się niezwykle zróżnicowane treści. Oprócz periodyków o charakterze społeczno-informacyjnym ukazywało się wiele pism poświęconych kulturze oraz trzecioobiegowe artziny

Iza Bartnicka, Agnieszka Kacprzyk, Grażyna Łuczko-Fijałkowska, Leokadia Szymańska. Por. J. Ciesielska, op. cit., s. 73 .

${ }^{6}$ Szczególnie pomocni i aktywni byli Mikołaj Novotny (Węgry), Mariella Nitosławska i Stefan Nitosławski (Kanada) oraz Aleksander Honory (RFN). Wielu ludzi z łódzkiej Filmówki, przede wszystkim środowisko Warsztatu Formy Filmowej, zaprosił na Strych Marek Janiak. Oprócz profesorów, Józefa Robakowskiego i Andrzeja Różyckiego, pomocni byli również studenci: Tomasz Snopkiewicz, Jacek Jóźwiak, Paweł Kwiek, Iwona Lemke, Elżbieta Skaryszewska. Kolejnym źródłem wymiany artystycznej były nawiązane jeszcze w latach siedemdziesiątych przez Janiaka i Kwietniewskiego kontakty z artystami mail artu, pochodzącymi przede wszystkim z Włoch. Wymienić należy też artystów takich, jak Guy Schraenen, Richard Boulez, Willy Kelly, Maya Gordon czy Paul Clark, którzy przebywali wówczas w Łodzi, bywali na imprezach strychowych, realizując artystyczne wystąpienia - performanse, instalacje i rozmaite wystawy. Por. www.kulturazrzuty.pl. 
powstające w środowisku kontrkultury ${ }^{7}$. Niezależnie od tematycznej rozpiętości zachowywały one zawsze autentyzm wypowiedzi. Ambicją twórców zinów było opisywanie rzeczywistości bez łgarstwa. Własny magazyn miał być miejscem prezentacji poglądów i zażartych dyskusji. Zapytana, do czego odnosi się nazwa magazynu, Zrzutowiec Grażyna Łuczko-Fijałkowska (Zofia) tłumaczy to w następujący sposób:

„Tango" to inspiracja tańcem, który jest tajemnicą, jest miotaniem się pomiędzy wściekłością a szczęściem, kilka kroków do przodu i znów do tyłu, charakteryzuje się improwizacją, nie ma kanonu kroków i póz, najważniejsza jest bliskość partnerów ${ }^{8}$.

„Tango” powstawało dzięki grupowemu zaangażowaniu - artyści własnoręcznie wykonywali prace do całego nakładu. Praca nad „Tangiem” była szalenie żmudna, pracochłonna i przypominała klasyczną manufakturę. Każdy autor przygotowywał cały nakład stron formatu A4, własnoręcznie wykonywał 200 stron, a następnie wspólnie składano je i zszywano w okładce z kartonu. Niekiedy osoba mająca dostęp do powielacza lub kserografu wyręczała kolegów w drukowaniu nakładu ich stron lecz większość artystów wykonywała je ręcznie przy pomocy narzędzi rysunkowych, malarskich, szablonów i fotografii. Teksty drukowano na powielaczu, sam fakt jego posiadania mógł zaprowadzić Zrzutowców do więzienia. Proces powstawania magazynu opisuje Grażyna Łuczko-Fijałkowska:

Tomek Snopkiewicz i Marek Janiak wieźli prace Łodzi Kaliskiej na wystawę do Paryża, gdzie nabyli powielacz. Aby przywieźć go z Francji do Polski, został rozłożony do ostatniej śrubki, a każdy element umieszczony w innej części małego fiata. W drodze powrotnej, podczas kontroli na polskiej granicy, jedna z prac - tekturowa małpka, której po pociągnięciu za sznurek spod pachy wyskakiwał duży chuj, tak spodobała się celnikom, że rozbawieni odstąpili od czynności kontrolnych. Tak rozmontowany powielacz dotarł do Łodzi. Innym razem, gdy jechałam na rodzinną wycieczkę do Włoch, dostałam zadanie zrobić 200 odbitek ksero jakiejś pracy czy tekstu. W Polsce przecież nie było jeszcze powszechnie dostępnych kserokopiarek. Nie starczyło już potem ani pieniędzy, ani miejsca w walizce na prezenty dla rodziny ${ }^{9}$.

${ }^{7} \mathrm{Na}$ polu drugoobiegowych publikacji główną rolę odgrywali zarówno organizatorzy i komentatorzy wystaw artystycznych, jak i redaktorzy pism o rozmaitym zasięgu i charakterze Janusz Bogucki, Jerzy Brukwicki oraz Marek Rostworowski. Sztuki wizualne przybliżał poznański „Czas Kultury” (od 1985 roku), krakowska „Arka” (1983-1989), wrocławska „Obecność” (1983-1988). Szczególnym uznaniem cieszył się zainicjowany przez Andrzeja Osękę miesięcznik „Kultura Niezależna”. W jego redakcji znaleźli się głównie publicyści, lecz dzięki działalności Osęki zamieszczano w nim także materiały dotyczące sztuki. Już w pierwszym numerze ukazał się obszerny tekst dotyczący nowych form współbycia artystów oraz zjawiska „pielgrzymowania po pracowniach". Wśród czasopism, w których problematykę sztuk wizualnych traktowano równorzędnie z innymi przejawami kultury, należy wymienić warszawski „Wybór” (1984-1988), mający charakter kulturalnego informatora, i „Szkice” (1984-1989), które zastąpiły przejętą przez władze „Sztukę”. W drugim obiegu dominowały relacje z bieżących wydarzeń; brakuje w nim poważniejszych diagnoz społecznej i artystycznej sytuacji czy polemik. Por. A.F. Pawlak, op. cit., s. 161.

${ }^{8}$ G. Łuczko-Fijałkowska, Łatwiej było działać w grupie. Rozmowa Moniki Stelmach z Zofia Łuczko, http://www.dwutygodnik.com/artykul/6135-latwiej-bylo-dzialac-w-grupie.html (dostęp: 15.11.2016).

9 Ibidem. 
Bezpośrednim przodkiem „Tanga” była wydawana od 1982 roku „Fabryka” — wydawnictwo będące rodzajem książki/katalogu zawierającego inicjatywy artystyczne. Powstało w celu podsumowania polskiego udziału w międzynarodowej imprezie „Konstrukcja w Procesie”, po zakończeniu której postanowiono wydawać ręcznie robione pismo. Fabryka była składana na Strychu z inicjatywy Marka Janiaka, który do pracy nad nią zaprosił wielu ludzi z łódzkiej Filmówki. Każdy jej egzemplarz był rodzajem kolekcji do wglądu dla wszystkich zainteresowanych; na podobnej zasadzie skonstruowany był późniejszy magazyn Zrzutowców, którego historia wiąże się ściśle z członkami grupy Łódź Kaliska. To przede wszystkim oni i ich sympatycy redagowali łódzki zin; wesoła, absurdalna postawa artystyczna Łodzi Kaliskiej zdominowała styl „Tanga”. Na jego łamach ukazywały się prace i teksty artystów z całego kraju. I choć było ono wytworem mikrospołeczności gromadzącej się na niewielkim łódzkim Strychu, magazyn funkcjonował w skali międzynarodowej - prace i strony do „Tanga” przysyłało wielu zagranicznych artystów, m.in.: Italo Mazza, Cavellini, Bruno Sapiente, William Xerra, Vittore Baroni, Carlo Pittore, Paolo Scirpa. Dzielono się w nich rozmaitymi koncepcjami, emocjami, planami, obrazem, wierszem i zgrywą. Projekt dawał ogromną dowolność w zakresie wyboru tematu i technik plastycznych ${ }^{10}$.

Magazyn Kultury Zrzuty jako niezależny organ wydawniczy ma nieocenioną wartość dokumentacyjno-źródłową i informuje pośrednio o rzeczywistości historycznej i kulturowej okresu, w którym wychodził. Wszystkie numery „Tanga” były czynionym na bieżąco zapisem niemalże wszystkiego, co mogło być zapisane. W wywiadzie dla zachodnich mediów reżyser z pokolenia Zrzutowców, Krzysztof Kieślowski, tak przedstawiał tamte czasy i polską rzeczywistość:

Pan naprawdę nie może pojąć, co to znaczy żyć w świecie, którego nie można opisać. Cechą pańskiego świata, Zachodu, jest to, że go zawsze opisywano i opowiadano o nim. Kiedy żyje się w świecie, który nie jest opisany ani nazwany, żyje się w nieustannej abstrakcji. Nie wiadomo, gdzie zaczyna się rzeczywistość. Nie wiadomo, jakie zasady rządzą tym światem ${ }^{11}$.

„Tango” pozwoliło łódzkiej wspólnocie opisać jej prywatny świat, a tym samym przechować wyrwaną socjalistycznej rzeczywistości autonomiczną przestrzeń. Powstało z autentycznej potrzeby odniesienia się do prywatnych doświadczeń "łódzkiego plemienia”, istotnej dla młodego człowieka tematyki erotycznej i szeroko pojętego „świata zabawy”. Wypada podkreślić, że „Tango” było nie tylko pismem artystycznym, lecz także dziełem sztuki formatu A4, powielonym w 100 (mówiło się właściwie o faktycznych 120 egzemplarzach nr 1 i 2) lub 200 (nr 4 i następne) egzemplarzach. Poszczególne prace składające się na konkretny numer magazynu

10 A.F. Pawlak, op. cit., s. 162.

11 V. Ostria, Przypadek i konieczność, przeł. M. Oleksiewicz, T. Lubelski, [w:] Kino Krzysztofa Kieślowskiego, red. T. Lubelski, Kraków 1997, s. 30. 
to niezależne dzieła, a zarazem część strukturalna estetycznej całości ${ }^{12}$. Ulubioną techniką autorów „Tanga” był montaż. Podstawowym jego tworzywem jest kolaż klisz, mix cytatów, imitująca twórczość innych artystów prześmiewcza stylizacja. Tak, jak w przypadku plastyki, tak w odniesieniu do języka na zasadzie montażu zestawiane są z sobą kontrastujące elementy, zderzane wartości artystyczne z pozaartystycznymi, związanymi z codziennym życiem. Oprócz dwuwymiarowych kolaży i licznych interwencji plastycznych na zastanym materiale fotograficznym chętnie stosowano przestrzenny bricolage - technikę zestawiania z sobą różnych elementów, które akurat znalazły się „pod ręką". Twórca „Tanga” to często bricoleur, który posługuje się łatwo dostępnymi, gotowymi, napotkanymi w swoim otoczeniu elementami i wykorzystuje je do własnych celów, by nadać im znaczenie inne niż wynikające $z$ ich pierwotnego przeznaczenia. Składa on i przestawia elementy układanki, nadając swojej pracy nowy sens.

Aktualia, odważne komentarze społeczne i środowiskowe to cechy charakterystyczne magazynu. W „Tangu” publikowane były manifesty, teksty, wywiady i liczne teksty autorskie. Styl i język, podobnie jak w wypadku większości trzecioobiegowych magazynów, ewoluował w stronę kolokwializmów, młodzieżowego slangu, pojawiały się erotyczne rysunki, dowcipy, słowa piosenek. W zinie Zrzutowców znalazły się miniaturowe dziełka sztuki i antysztuki oraz manifesty. „Antyprogram artystyczny" tworzyły rysunki, collages, stylistycznie opierające się na ironii, kpinie, żarcie, skandalu, atakowaniu innych zjawisk artystycznych. O życiu erotycznym artyści opowiadali $\mathrm{w}$ „Tangu” intensywnie i w najróżniejszych formach, stosując rozmaite środki wyrazu. Pismo zawierało też liczne dowcipy sytuacyjne związane z przebiegiem imprez, rozmaite psikusy płatane artystom, prywatne dyskusje i środowiskowe anegdoty. W magazynie znalazły się także listy i prywatne telegramy artystów, piosenki, zagadki i instrukcje dla czytelnika, będące propozycją wypróbowania pewnych zachowań i doświadczania określonych sytuacji.

Signum specificum magazynu Zrzutowców to korzystanie ze znamiennych sposobów kształtowania dyskursu, takich jak kojarzona z karnawałem i błazeństwem fragmentaryzacja, metaforyzacja, przeciwstawienia, hiperbolizacja. Stosowane środki stylistyczne i retoryczne pomagały unaocznić cechy konstytutywne tworzonego świata, w którym normą było częste odchodzenie od linearnego wywodu i kompozycja cechująca się luźnym powiązaniem nieraz odległych myślowo fragmentów. Konwencjonalny dyskurs nie pozwoliłby oddać charakteru kreowanej rzeczywistości. Ta „Biblia błaznów” dowodzi tego, czego próbują dowieść liczne performansy artystów tworzących magazyn - niespójność

12 Jedynie nr 3 „Tanga” był jednoegzemplarzową księgą i zawierał wykonaną przez Adama Rzepeckiego dokumentację pleneru w Teofilowie koło Spały, zorganizowanego w posiadłości Zbigniewa Bińczyka. W ciągu trzech lat pojawiło się dziewięć numerów „Tanga”, w tym jeden podwójny. Do tego wspomnieć trzeba „Wielkie Tango", które wykonane zostało podczas pleneru w Teofilowie w 1983 roku i przybrało kształt obiektu artystycznego. Istniało też kilka pism autorskich ze słowem „Tango” w tytule. Por. www.kulturazrzuty.pl. 
jest ciekawsza niż deformujący prawdę linearny porządek. Dlatego też „Tango” wytwarza treści, których stabilność i długie trwanie zawartych w nim sensów nigdy nie są pewne. Jest jak obraz malarza kubisty, który przedstawia dane zjawisko jednocześnie z kilku punktów widzenia. Jest też przestrzenią transgresji, otwartą na podważanie, kwestionowanie, a nawet dekonstrukcję aerotycznej rzeczywistości. Tak, jak w wypadku performatywnych wystąpień na Strychu, tak w odniesieniu do „Tanga” można powtórzyć za Zrzutowcem Józefem Robakowskim, że była to „sztuka prywatna”" ${ }^{3}$. Jej radykalizm i niezależność myśli sprawiały, że trzecioobiegowe magazyny uznawane były przez władzę za zagrożenie, podobnie jak opozycjonistyczna „bibuła”. Niekiedy nawet autentyczny młodzieńczy bunt wydawał się dalece bardziej niebezpieczny ${ }^{14}$.

$\mathrm{Na}$ początku lat osiemdziesiątych w niezależnym obiegu dominowały gazetki koncentrujące się głównie na tematyce muzycznej i podejmujące tematykę społeczną, zagadnienia dotyczące seksu i erotyzmu zaś zgodnie omijały wszystkie tytuły wydawane przez młodych, zaangażowanych twórczo i politycznie. W czasie strajków studenckich w 1981 roku wrocławski Ruch Nowej Kultury zaczął wydawać powielaczową gazetkę „Pomarańczowa Alternatywa”. W 1983 roku powstał redagowany przez Janusza Waluszkę, Wojciecha Jankowskiego i Krzysztofa Skibę „Homek” związany z Ruchem Społeczeństwa Alternatywnego, a od 1986 roku pojawiał się gdański nieregularnik „A Capella” związany z organizacją Wolność i Pokój, którego kontynuacją była „Mat' Pariadka”" ${ }^{5}$. Studiujący w Łodzi Krzysztof Skiba wydawał autorską gazetkę „Przegięcie Pały”, lecz dopiero pod koniec dekady nadciągnęła fala artzinów skupiających się na działalności artystycznej i twórczości alternatywnej, na przykład wyrosły z anarchistycznych inspiracji „brulion”

13 J. Robakowski, Sztuka Zrzuty, [w:] PST! Czyli sygnia nowej sztuki (or Signs of New Art) 19811984, red. J. Robakowski, Akademia Ruchu, Warszawa 1989, nlb.

${ }^{14}$ Składanie artystycznych pism było niewątpliwie sztuką wielkomiejską, środowiskową, a wydawnictwa te często miały charakter intelektualnej partyzantki. Korzeni „Tanga” można szukać w szerokim nurcie alternatywnych form książki jako obiektu. Przykładowo wymienić można powstałą w 1976 roku Abrupte Fable Pierre’a Alechinskiego i Christiana Dotremonta (członków Cobry), która przybrała formę harmonijkowo-książkowego parawanu, czy założony przez Phyllis Johnson magazyn „Aspen”, który był multimedialną przestrzenią artystycznej ekspresji. Wydawany zwykle w formie pudełka, mieścił w sobie poezję, teksty krytyczne, działania artystyczne oraz filmy i nagrania dźwiękowe muzyki eksperymentalnej, m.in. Johna Cage’a, Yoko Ono, Johna Lennona oraz Philipa Glassa. Jego poszczególne numery projektowali czołowi przedstawiciele amerykańskiej i brytyjskiej sceny artystycznej i ruchu Fluxus. Każdy numer magazynu, podobnie jak kolejne numery „Tanga”, zapraszał odbiorców do interakcji, wykraczał tym samym poza tradycyjne ramy pisma o sztuce. Por. S. Home, Gwałt na kulturze. Utopia, awangarda, kontrkultura. Od letryzmu do Class War, Warszawa 1993.

15 C. Kuta, Siła wolnego stowa $z$ powielacza. Pisma drugiego obiegu w latach 1980-1989/1990, [w:] Pokolenie '80. Niezależna twórczość młodych w latach 1980-89, Instytut Pamięci Narodowej Oddział w Krakowie, wystawa i katalog według koncepcji T. Boruty, Kraków 2010. Zob. także eadem, Wolne słowo - „oaza wolności” w czasach zniewolenia. Niezależna działalność wydawnicza w latach 1980-1989/1990, [w:] Pokolenie '80...; eadem, Niezależny ruch wydawniczy 1980-1989, [w:] NSZZ „Solidarnośç" 1980-1989, t. 2. Ruch społeczny, red. Ł. Kamiński, G. Waligóra, Warszawa 2010. 
(1986), w którym publikowali Marcin Świetlicki, Marcin Sendecki czy założyciel i naczelny redaktor Robert Tekieli. Na jego łamach kontestowano oficjalną kulturę, a także podważano dotychczasowe „solidarnościowe” autorytety, dyskutowano o nowych zjawiskach, jak punk rock czy graffiti. Ukazywały się w nim także teksty poetów-performerów z powstałej w Gdańsku formacji Totart, której jeden z liderów, Paweł Konjo Konnak, od 1985 roku tworzył zin „Gangrena” będący kontrpropozycją dla fanzinowego nurtu ${ }^{16}$. Wydawane przez Kulturę Zrzuty „Tango” było unikatowym medium, za pomocą którego w latach osiemdziesiątych artyści prezentowali przemilczane tematy erotyczne i na którego łamach konfrontowano upodobania autorów i zaprzyjaźnionych czytelników. Własnoręcznie składany zin stał się również interaktywną platformą dyskusji i w pewnym sensie pełnił on dla ówczesnych, rozsianych po kraju, twórców analogiczną funkcję do tej, jaką dziś pełni platforma społecznościowa Facebook powiadamiająca użytkowników o możliwości udziału w rozmaitych przedsięwzięciach i umożliwiająca zdawanie zeń relacji, stanowiąc jednocześnie pionierskie, artystyczne medium społecznościowe.

Artystyczne idee i tematyka erotyczna, która pojawiała się na łamach „Tanga”, wykraczały daleko poza tworzące je środowisko. Cyrkulacja dokumentacji sztuki była kluczowym dopełnieniem nowo powstałego modelu galerii - Strychu funkcjonującego na zasadzie „pola dla wolności”, gromadzącego zaangażowane w sztukę i życie twórcze jednostki. Tworzony poza oficjalną siecią produkcji i dystrybucji magazyn rozprowadzano z ręki do ręki, aby uniknąć cenzury. Magazyn stał się łącznikiem i polem wymiany, salą wystawową i elementem spajającym tę różnorodną społeczność artystyczną. „Jak się któremuś z panów spodobała dziewczyna, to obdarowywał ją »Tangiem «"- wspomina zaprzyjaźniona $z$ artystami Grażyna Łuczko ${ }^{17}$. Zrodzone w środowisku Kultury Zrzuty idee przekraczały granice miasta, ponieważ pismo rozdawano krytykom i znajomym w całej Polsce.

Zabiegi kompozycyjne w „Tangu” rzadko przybierały postać ironicznej trawestacji plastyki propagandowej. „Świat na opak” widoczny jest przede wszystkim w śmiałej twórczości erotycznej zawartej w magazynie, a także w języku wyśmiewającym "nowomowę" i populistyczne hasła władzy ludowej. „Tango" daje upust związanym z „dołem materialno-cielesnym” nieprzyzwoitościom, chętnie stosowanym przez Łódź Kaliską w sztuce akcji. Cechuje je również frywolność erotyczna i wesoły system obrazowy będący echem tzw. realizmu groteskowego. Terminem tym Michaił Bachtin określa specyficzny typ obrazowości, właściwy wszystkim formom ludowej kultury śmiechu. Groteskowy typ obrazowości to należąca do najstarszych metoda konstrukcji obrazów; odnajdujemy ją w mitologii

16 Konjo zamieszczał w nim osobliwe teksty o niełatwej do ustalenia tożsamości gatunkowej, z wyraźnie dominującym pure nonsensem i surrealizmem. Por. K. Skiba., Komisariat naszym domem. Pomarańczowa Historia, Warszawa 2014.

17 A.F. Pawlak., op. cit., s. 156. 
i archaicznej sztuce wszystkich ludów. Usunięty poza granice oficjalnej sztuki „realizm groteskowy” rozwija się i żyje w „niskich”, „niekanonicznych” jej dziedzinach: komicznej plastyce, maskach komicznych, posążkach demonów płodności czy obszernych dziedzinach literatury śmiechu związanej z uroczystościami typu karnawałowego. „Realizm groteskowy” z żywiołem materialno-cielesnym widoczny jest najpełniej $\mathrm{w}$ realizacjach fotograficznych i tworzonych specjalnie do „Tanga” kolażach o tematyce erotycznej oraz w całkowicie poświęconym seksualności specjalnym wydaniu tzw. Porno-Tanga, w którym znalazły się także zapisy performensów o erotycznym charakterze, realizowanych na łódzkim Strychu.

W zinie Kultury Zrzuty w różnorodny sposób korzystano z rysunku i fotografii, które służyły często do przedstawienia żartobliwych wypowiedzi o erotycznym charakterze, co było wyjątkowym w owym czasie wyznaniem wolności w sferze seksualnej obyczajności. W kolażach, rysunkach i plastycznych interwencjach na fotografiach ciało ukazywane jest ze zmysłową ekspresją, często w zwielokrotnionej postaci, podkreślając witalność, płodność i płynącą z erotyki przyjemność. Groteska związana z kulturą ludową przybliża i spokrewnia świat z człowiekiem poprzez podkreślanie ludziej biologii i ucieleśnienia. Z groteską łączy się wszystko, co zdecydowanie odchyla się od norm estetycznych, co podkreśla i hiperbolizuje momenty materialno-cielesne. Istotną cechą groteskowego obrazu jest ambiwalencja, bieguny zmiany - stare i nowe; to, co umiera i to, co wzrasta, początek i koniec. Groteskowe obrazy przedstawiają zjawisko w trakcie zmiany, w stanie nieukończonej metamorfozy, w stadium śmierci i narodzin, stawania się i wzrostu. Taki charakter mają obiekty z cyklu "Sztuka Żenująca” Marka Janiaka ${ }^{18}$ czy kolaże Adama Rzepeckiego, komponowane $\mathrm{z}$ fragmentów zdjęć roznegliżowanych kobiet, pochodzących z niemieckich pornograficznych magazynów. Z punktu widzenia klasycznej estetyki, czyli klasyki gotowego, skończonego istnienia, prace prezentujące postacie kobiet $\mathrm{z}$ multiplikowanym biustem wydają się pokraczne, szkaradne, albowiem proces cielesnego wzrostu, nadmiar, rozpad ciała i jego podział na części przeciwstawia się klasycznemu obrazowaniu ludzkiego ciała jako czegoś gotowego, skończonego, dojrzałego. Przedstawienie to jest w oczywisty sposób sprzeczne z plastycznym kanonem klasycznego antyku, który legł u podstaw estetyki renesansu i był istotny dla dalszego rozwoju sztuki. Bachtin twierdzi jednak, że w warunkach atmosfery jarmarcznej, gdzie ciało wiąże się z radością, celebracją i nieskrępowaniem, gdy ludzie się śmieją, w warunkach familiarnego kontaktu „[...] roi się od wyobrażeń groteskowego ciała; ciała, które spółkuje, wydala, obżera się, mowa nasyca się organami płciowymi

18 M. Janiak, Sztuka żenujaca, [w:] Żywa Galeria. Łódzki progresywny ruch artystyczny 19691992, t. 1. 1969-1981, red. J. Robakowski, Łódź 2000. 
[...] groteskowy obraz ciała tkwi także u podstaw ogólnoludzkich zasobów familiarnej i obelżywej gestykulacji”' ${ }^{19}$.

Przesada i multiplikacja organów płciowych, ukazana na prezentowanych w magazynie kolażach, ma jednak charakter pozytywny, aprobatywny i zabawowy. Groteska odkrywa możliwość istnienia jakiegoś zewnętrznego, gdzieś realnie zlokalizowanego zmysłowego świata - tak innego od oderotyzowanej PRL-owskiej rzeczywistości. Dzięki temu „Tango” wyprowadza poza szare granice pozornej i fałszywej aerotycznej zmarzliny lat osiemdziesiątych. Niezależnie od historycznej formy artystycznej, zrodzona przez ludową kulturę śmiechu groteska obrazuje powrót na ziemię „saturnowego złotego wieku”. Rzeczywistość nagle staje się obca, ponieważ odsłania możliwość istnienia świata autentycznego - alternatywnego świata prawdy erotyzmu i zmysłowości ${ }^{20}$. Warto zaznaczyć, że w groteskowym systemie obrazowania kobieta zawsze pozostaje w ścisłym związku z bachtinowskim „dołem materialno-cielesnym", ucieleśnia ten dół - poniżający i odradzający jednocześnie. Kobieta „sprowadzana na ziemię" jest „naczyniem poczęcia”, dlatego w obrazach groteskowych „zadziera kiecę i pokazuje miejsce, do którego wszystko zmierza i skad się wszystko bierze"21.

Zauważmy, że gdy łódzcy artyści tworzyli „Tango”, władza ludowa promowała obraz Matki Polki - odartej z seksualności i kobiecości. Zamieszczona w piątym numerze „Tanga” praca z 1983 roku pt. Pomnik Ojca Polaka to zdjęcie ukazujące członka Kultury Zrzuty, Adama Rzepeckiego, siedzącego na stołku w nieokreślonym bliżej domowym pomieszczeniu, ubranego tylko w spodenki sportowe i przykładającego do piersi niemowlę. Warto podkreślić, że z obrazami groteskowego ciała ściśle związane są sceny płodności i symbolicznie poszerzone obrazy karmienia piersią. Podstawową zasadą realizmu groteskowego jest właśnie degradacja polegająca na obniżeniu znaczenia wszystkiego, co wysokie, duchowe i idealne. Roznegliżowany portret artysty symulującego karmienie niemowlęcia można interpretować jako kpinę z promowanego przez państwo oderotyzowanego obrazu Matki Polki (sprowadzonej do funkcji reprodukcyjnych), opartego w dużej mierze na kulcie Matki Boskiej. To parodia propagowanych przez władzę i wpajanych społeczeństwu wartości. Tymczasem ciała w „Tangu” prężyły się, zaświadczając o wadze witalności i erotyzmu.

Eros jest siłą poruszającą zarówno fizyków jak poetów [...] Eros trwa mocniej niż życie i śmierć gdyż jednoczy ludzi w „tryumfalnym śmiechu”, śmiechu, który przenosi nas na chwilę w inną rzeczywistość, gdzie ginie lęk, zatraca się ból „pod wiecznym światłem zatrzymanego czasu./Bez tej formy, która nas uwięziła"22.

19 M. Bachtin, Twórczość Franciszka Rabelais'go a kultura ludowa średniowiecza i renesansu, przeł.

A. i A. Goreniowie, oprac., wstęp, komentarze i weryfikacja przekładu S. Balbus, Kraków 1975, s. 440.

20 Ibidem, s. 113.

21 Ibidem, s. 346.

22 C. Miłosz, Nieobjęta ziemia, Łódź 1987 (drugi obieg), s. 54. 
Warto zaznaczyć, że nurt erotyczno-seksualny jest niezwykle rzadki w polskiej twórczości neoawangardowej i podejmowany był w szerszym zakresie jedynie przez Natalię LL i Ewę Partum. Tymczasem zmysłowość, tradycyjnie uznana za niższą warstwę człowieka, podporządkowana temu, co wyższe, czyli rozumności, $\mathrm{w}$ "Tangu” zostaje wyniesiona na piedestał. W magazynie przeważają obrazy życia materialno-cielesnego - jedzenia, picia, spółkowania. Ciało z „Tanga” to zawsze ciało zapładniające lub zapładniane, rodzące-rodzone, pożerające-pożerane, pijące, wydalające itp. W "realizmie groteskowym” żywioł materialno-cielesny jest pierwiastkiem pozytywnym i nie występuje w postaci wyizolowanej, prywatnej, lecz traktowany jest jako uniwersalny, powszechny i nie pozwala oderwać się od całości, nie dopuszcza do izolacji i zamknięcia. Podejmowanie „niewidzialnej", przemilczanej tematyki to dowód, że młodzi i energiczni uczestnicy Kultury Zrzuty zachowali autentyczną postawę, a ich ambicją było opisywanie rzeczywistości i własnej biologii bez łgarstwa.

W „Tangu” seks i erotyka pojawiają się zarówno pod postacią incydentalnych, żartobliwych kolaży, jak i w formie całych cykli, na przykład w „Sztuce męskiej” Adama Rzepeckiego, w której króluje erotyzm daleki od finezji i wyrafinowania. Jego celowo prymitywna estetyka wskazuje na kpinę z pornografii. W realizacjach Rzepeckiego oprócz zwielokrotnionych ogromnych biustów pojawia się zmultiplikowany, kolorowy fallus wykonany w stylistyce pop-artu nawiązującej do prac Andy’ego Warhola. Ukazujące sceny kopulacji kolaże artysta opatrzył prześmiewczymi, wulgarnymi hasłami. Erotyczne nawiązania to bardzo istotna, transgresyjna cecha „Tanga”. Na jego łamach członkowie Kultury Zrzuty dokonywali wielokrotnie plastycznych interwencji, ingerując w rysunki i zdjęcia innych twórców, „dekorując je” genitaliami, biustami lub komentarzami o groteskowym, erotycznym wydźwięku. W serii prac pt. „Sztuka męska i inna” artysta włączył pornografię do repertuaru prac Łodzi Kaliskiej. Cykl prześmiewczych erotycznych zdjęć i kolaży prezentowany był nie tylko w „Tangach”, lecz także w trakcie ekstrawaganckich festiwali artystycznych, między innymi na tzw. Festiwalu Porno na łódzkim Strychu w 1985 roku czy podczas plenerów sztuki. W trakcie pleneru w Teofilowie w 1985 roku, w zarejestrowanym monologu pt. Wyznania zboczeńca, członek Łodzi Kaliskiej i twórca stron do „Tanga”, Andrzej Kwietniewski, wyznaje, że to właśnie fakt szczerego przyznawania się do anomalii seksualnej, za jaką należy uznać publiczne obnażanie się, przysporzył mu rzesze miłośniczek płci przeciwnej. Jak wskazuje Jolanta Ciesielska, artysta lubił, podobnie jak pozostali członkowie Łodzi Kaliskiej,

grać role niestrudzonego kochanka, w czym wydatnie rywalizował z ulubieńcem starszych kobiet Andrzejem „Makarym” Wielogórskim, słodkim chłopczykiem w marynarskim ubranku [...] natomiast Marek Janiak najbardziej lubił pokazywać tors, i to z byle powodu. Poza tym zawsze wybierał rolę dość obcesowo zachowującego się wobec kobiet kierownika planu, narratora, reżysera. Natomiast w serii dokamerowych performances pt. „Ćwiczenia wyzwalające” uporczywie udawał naukowca-empiryka i wówczas nie rozbierał się wcale. [...] Kondycja 
fizyczna i rzeźba ciała jako elementy atrakcyjności męskiej były niemal zupełnie przez nich pomijane $e^{23}$.

Zauważmy, że twórca przygotowujący strony do „Tanga” uwzględniał odbiorcę, zwykle mówił bowiem do konkretnych, znanych sobie czytelników. Autorskie strony prezentowały sztukę osobistą, śmiałą, ale szczerą, kreowaną dla odczuwających podobnie przyjaciół, którzy częstokroć byli najsurowszymi krytykami. Wiele prac tworzących pismo koresponduje z sobą, co czyni magazyn „inkarnacją dialogu" z artystyczną tradycją i współczesnością Zrzutowców. Wielokrotnie przekraczano granice klasycznej narracji, zmierzając w stronę rozmaitych form interaktywności. Choć poszczególne prace zwykle były opatrzone podpisem konkretnego twórcy, ich intencją nie było często jedynie eksponowanie osobistej twórczości, lecz przekroczenie jej i nawiązanie dialogu wiodącego do współtworzenia. Chętnie też opatrywano artystycznym komentarzem dokumentacje zabawowych, nawiązujących do seksualności akcji Kultury Zrzuty. W magazynie pojawia się także poezja o erotycznym wydźwięku:

wielkie cyce potwornie wielkie cyce jak wiadra

cholernie pojemne wiadra wielkie

ogromne cycki $[\ldots]$

jak wory z piachem

jak dojrzałe dynie

albo jak kule ziemskie ${ }^{24}$.

W pracach o tematyce erotycznej pojawia się zwykle nadmiar - zwielokrotnione piersi, hiperbolizacja brzucha, fallusa, epizody oddawania moczu. Zawarte w „Tangu” erotyczne, żartobliwe bon moty, takie jak: „Żądamy wielkich cyców za małe pieniądze” czy „Poranne wzwody od przyrody”, mają dziś zabawowy wydźwięk, lecz w oderotyzowanym PRL-u, w którym artyści bądź wystawiali w kościołach, bądź poświęcali się sztuce konceptualnej, Eros, który opanował łódzki zin, przypominał z całą mocą, że doświadczamy świata także przez cielesność. Należy podkreślić, że to właśnie za pośrednictwem języka odbywają się najbardziej istotne dla człowieka procesy autostanowienia. Stworzenie własnego stylu oznacza brak zgody na to, by granice naszego namysłu wyznaczał język „dany do używania”. Chęć wyrażenia prawdziwego stanu umysłu sprawiła, że Zrzutowcy opisywali świat $\mathrm{w}$ niepowtarzalnym, autorskim słowniku przesiąkniętym erotyzmem i zmysłowością. Sposób, w jaki konstruowali magazyn, pozwalał odbiorcy na pewną dowolność $\mathrm{w}$ poruszaniu się $\mathrm{w}$ obrębie przedstawionego $\mathrm{w}$ nim zmysłowego świata. Idee, pomysły, oceny i rozmaite propozycje przedstawiane są w nim często nieliniowo, a narracje wizualne i tekstowe zwykle nakładają się, co ma na celu nieustanne zaskakiwanie, angażowanie czytelnika i skłonienie go do polemik.

23 J. Ciesielska, op. cit., s. 75.

24 M. Janiak, Poemat o wielkich cycach, [w:] Kultura Zrzuty, Akademia Ruchu, Warszawa 1989, nlb. 
Permanentna rozwiązłość, rozpasanie, demoralizacja, skandaliczne praktyki twórców „Tanga” naruszały bardzo często obyczaje, wywołując ukrytą w PRL-u tematykę seksualną. Eksponowanie narządów płciowych i rubaszny język przekleństw oznaczał klęskę władzy nad ludźmi i był śmiechem prawdy wyrażającej się w rozpasaniu i obraźliwych słowach. Karnawałowa frywolność znajdowała się zawsze w centrum wszystkiego, co nieoficjalne, co ilustrować miało ścisłe relacje między rozpadem a odnowieniem. Zauważmy, że w prywatnej sferze „świata odwróconego" rubaszne odniesienia do ciała i genitaliów odegrały wiodącą rolę, podobnie jak w groteskowym obrazie pozostającego poza oficjalną sferą karnawału, w trakcie którego istniały niezliczone przejawy nadużyć słownych i kpin obficie wypełnionych cielesnymi określeniami.

O częstym podejmowaniu wątków erotycznych na łamach magazynu wypowiada się w charakterystyczny dla siebie sposób Zrzutowiec, malarz i performer Jacek Kryszkowski, który w 1984 roku, w dziewiątym numerze „Tanga”, pytał:

Czy dziwić ma ciągła troska, z jaką Tango śledzi społeczeństwo i jego pornografię? Czyż czynnościom związanym $\mathrm{z}$ wzajemnym pobudzaniem się zainteresowanych rozkoszą nie narzuca się statusu intymności? Czyż nie jest to teren ujawniania się zalet, jak i preferowanie manipulacji, które jako obszar niespotykanej kompensacji wartości, miejsce odwetów za niepowodzenie czy wyrażania swego rozgoryczenia i buntu wobec nieprzychylnej oceny świata. [...] Czytelników rozdrażnionych tym, że w Tangu odnajdują jedynie podniecenie i rozładowują się wpatrzeni w którąś z fotografii nie będę pocieszał. Nic nie wydaje się tak jasne jak społeczeństwo pornografii. W jego stosunku do erotyki widać niechęć do własnych dociekań, uległość wobec kulturowych osiągnięć człowieczych: religii, zwyczajów, nauki czy ideologii Wschodu i Zachodu. Na tym można ćwiczyć dystans swój do własnej głupoty czy zamiarów uprawiania sztuki ${ }^{25}$.

Dzięki temu, że czytelnik „Tanga” bywał zwykle współuczestnikiem opisywanych w nim sytuacji, magazyn stał się agorą środowiska związanego z łódzkim Strychem. Podobnie jak Strych, magazyn Kultury Zrzuty był autonomiczną przestrzenią, w której artyści uruchamiali procesy związane z artystyczną autokreacją, tworząc oryginalny, specyficzny sposób narracji dotyczący erotyzmu i seksualności. „Tango” stanowiło odrębne uniwersum dające Zrzutowcom szansę na autentyczne wypowiedzi i nieskrępowaną niczym autoekspresję w sferze artystycznej i erotycznej. Dziś łódzki magazyn pozwala pojąć charakter „świata w budowie”, przyglądać się rzeczywistości Kultury Zrzuty będącej płynnym konstruktem podlegającym nieustannym zmianom. Twórcza siła magazynu miała źródło w negocjacjach $\mathrm{z}$ tradycją i kulturą, we wprowadzaniu wciąż nowych jakości, w mocy zaskoczenia, cieszenia się absurdem, erotyką i ztabuizowanym w PRL-u seksem. Stworzenie własnej, alternatywnej rzeczywistości oferowało akceptację mikrospołeczności, potrzebną do działania i życia „według siebie”. Angażując się w produkcję obrazoburczego „Tanga”, członkowie outsiderskiego ruchu przebijali się przez olbrzymi mur zbudowany ze społecznych dogmatów, naruszali tabu, poszukując

25 J. Kryszkowski, Próby łamania KIJA, [w:] Listy do E.K. 1986-1987, maszynopis nlb; idem, Osobisty punkt obserwacji fauny twórczej, „Tango” 1984, nr 5, nlb. 
alternatywnych sposobów oglądania świata. Magazyn stał się dla łódzkiej kontrkultury prywatną ,instrukcją obsługi rzeczywistości”, tłumaczem wspólnotowych zachowań, interpretatorem wielu artystycznych, wspólnie przeżytych sytuacji. Dlatego też „Tango" pozostaje dziś wielkim archiwum wesołej, swobodnej, sybaryckiej postawy przyjmowanej wobec aerotycznej rzeczywistości przez artystów dążących do totalnej emancypacji.

Spektrum postaw wypracowanych wobec kultury, a ujawnianych na łamach „Tanga”, było ogromne, przekraczało kontestację, dryfując znacznie mocniej w stronę podtrzymującej wspólnotę rytualnej zabawie. Bunt, wyrażany w zamieszczanych $\mathrm{w}$ magazynie pracach, nie spełniał się $\mathrm{w}$ negacji, przekraczając anarchizujący nihilizm. Artystyczne wystąpienia miały charakter twórczych propozycji podających jednocześnie w wątpliwość wszelkie tak zwane „zdroworozsądkowe" i niekwestionowane prawdy. Magazyn Zrzutowców to strefa wymiany, świadomie tworzona przestrzeń wolności. Jak deklarował w zamieszczonym w pierwszym numerze „Tanga” tekście Jacek Kryszkowski, „[c]ałą tę możliwość wygłaszania każdej herezji zawdzięczam waszej tolerancji wobec wszystkich dokonanych tu przedstawień" ${ }^{26}$.

Twórcy „Tanga” dokonali wielu przekroczeń - magazyn był „dialogicznym medium", zachęcał do zabrania głosu, wyrażenia własnego zdania w sferze seksualności. Zin emanował śmiałą erotyką, przedstawiając ją z "przymrużeniem oka”, w groteskowym, radosnym stylu, udowadniając, że oprócz wolnej, nieskrępowanej ekspresji artystycznej kwintesencją życia jest także Eros. Oparty na ironii, kpinie i oscylowaniu na granicy skandalu styl łódzkiego „Tanga” odróżniał się zdecydowanie od innych powstających wówczas w Polsce, niezależnych wydawnictw artystycznych, tj. wrocławskiego „Luksusu” czy zinu warszawskiej Gruppy. Pismo Zrzutowców jest jak kostium błazna - pozszywane z kolorowych strzępków, rozkładające kulturę na pstrokate fragmenty, złożone z chaotycznych kawałków tworzących dziwaczne kombinacje. Kalejdoskopowa logika i umiejętnie zakomponowany chaos sprawiają, że kontrowersyjny magazyn wytwarza formy dyskursywne, w których możliwość finalnego ustanowienia sensu jest $\mathrm{z}$ góry zanegowana.

W kolejnej dekadzie wielu artystów wywodzących się z Kultury Zrzuty, na przykład Zbigniew Libera, zaangażowało się w nurt tzw. sztuki krytycznej, komentującej mechanizmy dyscyplinowania ciała. Twórcy, którzy w latach dziewięćdziesiątych byli aktywni w tym nurcie, zajęli się zagadnieniami dostosowywania ciała do ideałów społeczeństwa konsumpcyjnego, tresowania, ucieleśniania ról płciowych. W niezwykłym tempie zaczęła się rozwijać także cyberprzestrzeń zmieniająca nasze postrzeganie cielesności ${ }^{27}$. Inną drogą poszli niegdysiejsi wydawcy „Tanga” z grupy Łódź Kaliska, którzy po transformacji rozpoczęli tzw. okres New

26 J. Kryszkowski, Tylko tam, gdzie jestem, „Tango” 1983, nr 1, nlb.

27 R. Kluszczyński, Sztuka interaktywna. Od dzieła-instrumentu do interaktywnego spektaklu, Warszawa 2010. 
Pop. Kaliszanie zaczęli organizować profesjonalne, ogólnopolskie castingi, podczas których wyłoniono m.in. najpiękniejszą „Orlicę Polski” (projekt pt. „Godło” przeznaczony dla magazynu „Playboy” ${ }^{28}$. Natomiast jednym z wydarzeń obchodów dwudziestolecia Łodzi Kaliskiej w 1999 roku był wykład Marka Janiaka pt. Romeo w pierwszym aucie w Małej Galerii ZPAF w Warszawie. Prelegent przy pomocy odpowiednich plansz, zdjęć i wykresów anatomicznych objaśniał zgromadzonym, co musi mieć, a czego absolutnie nie posiadać piękny mężczyzna:

Pod oczami powinien mieć lekkie wory, ale nie za duże. Włosów powinien mieć nie za dużo i nie za mało. Usta mocno zarysowane, ale nie przypominające szparki. Żadnych włosów na klatce piersiowej, nogi szczupłe, lekko kabłąkowate, brzuch płaski, ale nie umięśniony ${ }^{29}$.

Jak podkreśla wieloletnia komentatorka działań grupy, J. Ciesielska, praca $\mathrm{z}$ ciałami modeli przestała się różnić od pracy nad każdym innym projektem komercyjnym, przypominając pracę nad reklamą. Autorka zauważa, że erotyzm w okresie „New Pop” zmierzał w kierunku szmirowatej dosłowności, kiczowatego gestu, degradującego godność kobiety; sprowadzał modelki do roli towaru i manekina. Jako przykład podaje prace pt. Sklep nocny, gdzie nagie ciała modelek wtłoczone zostały między brudne sklepowe półki, oraz serię fotografii stworzonych z myślą o łódzkim „Festiwalu Czterech Kultur”, na których kobiety ubrane w jednakowe czepki kąpielowe i bieliznę siedzą na powiększonych do ogromnych rozmiarów lodach włoskich, czy wielkoformatowe fotografie z serii pt. „Niech sczezną mężczyźni”, prezentowane w 2009 roku w warszawskim CSW, ukazujące kobiety markujące pracę "prawdziwych mężczyzn” ${ }^{30}$. Po ostatniej z wystaw na blogu „artblox" pojawił się wymowny wpis, przywoływany przez krytyczkę:

Uprzedmiotowienie poprzez ciało jest obraźliwe, zwykle nie chcemy być traktowane jako cyce, nogi, penisy - ale jako ludzie. Wydaje się to dość oczywiste ${ }^{31}$.

Z biegiem lat artyści tworzący „Tango” zaczęli ujmować tematykę ciała i seksualności w rozmaity sposób, ale należy pamiętać, że prezentację zróżnicowanych postaw wobec erotyzmu pomógł uwolnić ręcznie składany na łódzkim Strychu magazyn. Jest on nie tylko „pamiętnikiem” Kultury Zrzuty, lecz także zwierciadłem wyzwań stojących przed młodymi ludźmi w latach osiemdziesiątych. Przez pryzmat „Tanga” można przyglądać się ówczesnemu kontrkulturowemu życiu artystycznemu. Tworzone przez uczestników tej kultury rękodzieło, wydawane pod banderą „Arystokraci wszystkich krajów łączcie się”, pozostaje dziś nieocenioną pamiątką artystycznych wydarzeń, indywidualnych poszukiwań twórczych,

28 E. Nowina-Sroczyńska, Szkic do antropologicznej opowieści o New Pop, [w:] New Pop, Wydawca: Stowarzyszenie Artystyczne Łódź Kaliska, Łódź 2004, b.n.s.

29 J. Ciesielska, op. cit., s. 75.

30 Fotografie z tego cyklu prezentowane były w Warszawie w CSW i w Łodzi w ramach majowego Festiwalu Fotograficznego w 2009 roku.

31 J. Ciesielska, op. cit., s. 76. 
skandalicznych aktów oraz wszechogarniającej zabawy „nakręcającej” ducha gromadzącej się na Strychu wesołej społeczności.

Smutek PRL-u był dla łódzkiej wspólnoty jak dżuma. Społeczność, którą łączyła sprawność umysłu, bystrość i spryt, barwnie portretuje Dekameron wcześniejszy od „Tanga” o pół tysiąclecia. Bohaterowie Giovanniego Boccaccia, podobnie jak Kultura Zrzuty, stworzyli alternatywny świat, prywatne universum, które pozwoliło im oderwać się od rzeczywistości zarazy, przed którą się schronili. I choć „Tanga” nie umieszczono, tak jak włoskiego dzieła, w indeksie ksiąg zakazanych, jego tworzenie wymagało bezkompromisowej i autentycznej postawy, która w świecie spychającym erotyzm na margines w zabawowy sposób afirmowała ludzką biologię. Dzięki temu, że uczestnicy Kultury Zrzuty zdołali zachować autentyczność, dzisiejszemu czytelnikowi biorącemu do ręki ten symboliczny portret łódzkich „profanów” z uśmiechem polecić można to, co swoim czytelnikom zalecał François Rabelais:

Przyjacielu, coś jął się tej Księgi,

Wszelki smutek chciej rozpędzić z czoła

I czytając nie gorszyć się zgoła

Choć nauczyć niewiele nas zdoła,

Jeno śmiechu da nieco czasami

To lekarstwo najlepszym się zda mi

Na zgryzotę, co sercu dopieka

Lepiej śmiechem jest pisać niż łzami

Śmiech to szczere królestwo człowieka ${ }^{32}$.

\section{Bibliografia}

Bachtin M., Twórczość Franciszka Rabelais'go a kultura ludowa średniowiecza i renesansu, przeł. A. i A. Goreniowie, Kraków 1975.

Ciesielska J., Anioł w piekle (rzecz o strychu), [w:] Bóg zazdrości nam pomyłek. Jubileusz 20-lecia pracy artystycznej grupy Łódź Kaliska, Łódź 1999.

Ciesielska J., Miejsca. Lata 80. w Polsce, [w:] Pokolenie 80. Niezależna twórczość młodych w latach 1980-89, Instytut Pamięci Narodowej Oddział w Krakowie, wystawa i katalog według koncepcji T. Boruty, Kraków 2010.

Ciesielska J., Trzy dekady Łodzi Kaliskiej. Zagadnienie erotyki w działaniach tej grupy, [w:] Biała Aura, Darłowo 2009.

Ciesielski A., Kultura Zrzuty, [w:] Sztuka poszukiwania decyzji. Dekada 1980-1990. Wybór tekstów, Koszalin 1990.

Home S., Gwalt na kulturze. Utopia, awangarda, kontrkultura. Od letryzmu do Class War, przeł. E. Mikina, Warszawa 1993.

Janiak M., Podwójny bezczelny komfort bycia, „Tango” 1984, nr 6.

Janiak M., Poemat o wielkich cycach, [w:] Kultura Zrzuty, Akademia Ruchu, Warszawa 1989.

32 F. Rabelais, Do czytelnika. Ksiegga pierwsza. Żywot wielce przeraźliwy wielkiego Gargantui, ojca Pantagruelowego, niegdy skomponowany przez mistrza Alkofrybasa, Abstraktora Piatej Esencji. Ksiega pełna pantagruelizmu, [w:] Gargantua i Pantagruel, przeł. T. Żeleński (Boy), Warszawa 1988, s. 54. 
Janiak M., Sztuka żenująca, [w:] Żywa Galeria. Łódzki progresywny ruch artystyczny 1969-1992, t. 1. 1969-1981, red. J. Robakowski, Łódź 2000.

Kluszczyński R., Sztuka interaktywna. Od dzieła-instrumentu do interaktywnego spektaklu, Wydawnictwa Akademickie i Profesjonalne, Warszawa 2010.

Kryszkowski J., Osobisty punkt obserwacji fauny twórczej, „Tango” 1984, nr 5.

Kryszkowski J., Próby łamania KIJA, [w:] Listy do E.K. 1986-1987, maszynopis 1986.

Kryszkowski J., Tylko tam gdzie jestem, „Tango” 1983, nr 1.

Kuta C., Niezależny ruch wydawniczy 1980-1989, [w:] NSZZ „Solidarność” 1980-1989, t. 2. Ruch społeczny, red. Ł. Kamiński, G. Waligóra, Warszawa 2010.

Kuta C., Siła wolnego słowa z powielacza. Pisma drugiego obiegu w latach 1980-1989/1990 [w:] Pokolenie '80. Niezależna twórczość młodych w latach 1980-89, Instytut Pamięci Narodowej Oddział w Krakowie, wystawa i katalog według koncepcji T. Boruty, Kraków 2010.

Kuta C., Wolne słowo - „oaza wolności” w czasach zniewolenia. Niezależna działalność wydawnicza w latach 1980-1989/1990, [w:] Pokolenie '80. Niezależna twórczość młodych w latach 1980-89, Instytut Pamięci Narodowej Oddział w Krakowie, wystawa i katalog według koncepcji T. Boruty, Kraków 2010.

Łuczko-Fijałkowska G., Łatwiej było działać w grupie. Rozmowa Moniki Stelmach z Zofią Łuczko, http://www.dwutygodnik.com/artykul/6135-latwiej-bylo-dzialac-w-grupie.html.

Miłosz C., Nieobjęta ziemia, Łódź 1987 (drugi obieg).

Nowina-Sroczyńska E., Arystokraci wszystkich krajów łączcie się! Szkic do antropologicznej opowieści o Łodzi Kaliskiej, „Polska Sztuka Ludowa. Konteksty” 2004, nr 65.

Nowina-Sroczyńska E., Piotrkowska 149. Strych - przestrzeń pozbawiona kurtuazji, [w:] Przestrzenie i ludzie. Konteksty antropologiczne, red. G.E. Karpińska, A. Krupa-Ławrynowicz, Łódź 2015.

Nowina-Sroczyńska E., Szkic do antropologicznej opowieści o New Pop, [w:] New Pop, Wydawca: Stowarzyszenie Artystyczne Łódź Kaliska, Łódź 2004.

Ostria V., Przypadek i konieczność, przeł. M. Oleksiewicz, T. Lubelski, [w:] Kino Krzysztofa Kieślowskiego, red. T. Lubelski, Kraków 1997.

Pawlak A.F., Tworzenie alternatywnych rzeczywistości. Ruch artystyczny Kultura Zrzuty - perspektywa antropologiczna, Łódź 2016.

Rabelais F., Do czytelnika. Ksiega pierwsza. Żywot wielce przeraźliwy wielkiego Gargantui, ojca Pantagruelowego, niegdy skomponowany przez mistrza Alkofrybasa, Abstraktora Piatej Esencji. Księa petna pantagruelizmu, [w:] Gargantua i Pantagruel, przeł. T. Żeleński (Boy), Warszawa 1988, s. 54.

Robakowski J., Kultura Zrzuty, „Neue Kunst in Europa (NIKE)” 1984, nr 3.

Robakowski J., Kultura Zrzuty, [w:] Nieme Kino II, oprac. M. Janiak et al., Antwerpia 1984.

Robakowski J., Kultura Zrzuty, [w:] Teksty interwencyjne 1970-1995, Słupsk 1995.

Robakowski J., Pitch-In Culture, [w:] Poolse 'avant-garde', Antwerp 1985.

Robakowski J., Sztuka w poszukiwaniu miejsca, Koszalin 1988.

Robakowski J., Sztuka Zrzuty, [w:] PST! Czyli sygnia nowej sztuki (or Signs of New Art) 1981-1984, red. J. Robakowski, Warszawa 1989.

Schechner R., Performatyka. Wstęp, przeł. T. Kubikowski, red. przekł. M. Rochowski, Wrocław 2006.

Skiba K., Komisariat naszym domem. Pomarańczowa Historia, Warszawa 2014.

Świetlik A., Dwa kroki do przodu i jeden do tytu, czyli tango ze Świetlikiem, [w:] Andrzej Świetlik w rozmowie z Adamem Mazurem i Mariuszem Chacińskim, http://www. fototapeta.art.pl/2002/ asw.php. 


\section{Body in disembodied reality. The „Pitch-In Culture” and „Tango"}

\section{Summary}

This is an essay about PITCH-IN CULTURE - an alternative current, alternative group of artists, who in the 1980s in Lodz had created an autonomic space, an artistic shelter which let them function away from an official, mainstream structures of life and its culture designed by the state. Counterculture from Lodz, rebelling against reality and fictional freedom created by authorities, found its space in the city centre, in the attic of one of townhouses. THE ATTIC had become an agora of underground, place of transgression of enforced schemes, clichés, patterns and truths. According to an idea - DO IT YOURSELF — DIY they published handmade magazine with art works that aroused or were related to sexual desire, often incorporating nude figures. 